\section{Princípios de administração financeira}

Por Lawrence P. Gitman. 1 ed.- Trad. Francisco José dos Santos Braga. Rev. téc. João Carlos Hopp, PhD, da EAESP/FGV. São Paulo, Harper \& Row do Brasil, 1978. 580 p. Apêndice com tabelas de valor presente, glossário, índice remissivo.

Uma das causas do atraso do Brasil no campo da administração de empresas como um todo é a quase inexistência de boas obras de autores brasileiros e, sem dúvida aiguma, a péssima tradução de obras estrangeiras lem geral norteamericanas).

Quando nos concentramos, então, quer no campo da administração contábil, quer no campo da administração financeira, chegamos a uma situação de verdadeiro caos, pois os tradutores, bons conhecedores da língua inglesa le portanto ótimos para a tradução de romances do tipo irving Wallace, Harold Robbins ou Morris West...), não conhecem os termos técnicos nos dois campos de conhecimento mencionados no início deste parágrafo, fazendo verdadeiras barbaridades - para não dizer crimes contra o ensino no Brasil e tornando quase incompreensível a leitura de livros técnicos, especialmente na área de administração contábil e/ou financeira.

Exemplos típicos \{quicá clássi-. cosl do que foi afirmado são, por exemplo: a expressão good-will, traduzida como "boa vontade no balanço", para o que se conhece como "fundo de comércio" lou "aviamento", utilizado pelos contadores brasileiros mals ortodoxos); staff, que em inglês, em um organograma, pode significar um órgão de assessoria, ou às vezes, em uma frase, pode ser entendido, no sentido lato do termo, como o pessoal que trabalha em uma empresa. Ocorre então que, na maior parte das traduções, encontramos em um organograma, geralmente em linha pontilhada, um órgão de pessoal (sic!), ou ainda, um órgão de assessoria em linha cheia (demonstrando ser um órgão executivol, e o pior de tudo é quando da explicação do organograma e/ou das funções a serem exercidas pelos vários órgãos lou departamentos) verifica-se que o órgão de pessoal, na linha pontithada, assesso ra o presidente e/ou outro execut।vo qualquer $e$, ao mesmo tempo, o órgão de pessoal é, na linha cheia, um órgão com funções típicas de pessoal làs vezes denominado, para confundir um pouco mais o leitor, de órgão de assessoria).

Sem querer utilizar palavras mais fortes ainda, outro verdadeiro crime contra o ensino de administracão financeira no Brasil foi a tradução de um livro clássico na literatura, publicado nos EUA pela Columbia University Press em 1963, graças a um auxilio da Ford Foundation, conforme o próprio autor menciona no inicio de sua obra, de 170 páginas, traduzida para o português em 1969; a segunda edição (sic!) foi publicada em 1973 e a terceira edição (sic!) em 1977 , com 221 páginas. Fato estranho haver a segunda e a terceira edições em português, pois, em inglês, a edição de 1963 não foi alterada. O que não é estranho é o número de páginas da edição em português ser maior que o número de páginas da edic̣ão em inglês, coisa muito comum nas traduções iserá que somos mais profícuos para escrever, uma vez que são mínimas as diferenças do tipo e/ou tamanho da letra de impressão?).

Pois bem, nesta obra clássica, o que se conhece em inglês por IRR (internal rate of return) ou taxa in-. terna de retorno e NPV inet present valuel ou valor presente líquido, conceitos básicos para conhecer-se capital budgeting, e depois a questão de custo do capital, está traduzıdo por pelo menos cinco denominações diferentes, sem contar as traduções de outros conceitos fundamentais, os quais, conforme a págına, também possuem denominações désiguais.

O livro de Gitman é a tradução de obra cujo original é recente lem Inglês a edição é de 1976), fato este relativamente raro no Brasil, pois além de mal feitas as traducões referem-se a edições antigas em inglês, quando existem edições no original muito mais modernas e, conseqüentemente, absorvemos como tecnologia ou o termo mais em moda know-how bastante obsoleto.

Exemplo também típico desta última afirmativa é um livro de administração financeira escrito por um professor que na época era da Michigan State University latualmente leciona em outra universidadel, cuja tradução para o português, em dois volumes, é boa (fato raríssimo!), porém foi baseada na segunda edição em inglês, de 1963 - com sucessivas edições (ou relmpressões?) em português, tal o sucesso da obra; em inglês, todavia, já se encontra na sexta edição, com conceitos bem mais modernos e sofisticados.

Gitman dividiu sua obra em 8 partes, com um total de 26 capitulos dependendo do assunto; como glossário existente ao final, em ordem alfabética em português, seguido entre parênteses do termo em inglês e do significado do mesmo, a trađucão não só é perfeita e uniforme mas, este fato aliado à maneira bem simples e didática pela qual o autor expõe o assunto torna possivel ao leitor, até sem professor para orientá-lo, ler pouco a pouco o livro e assim ter uma noção básica do que seja administração financeira.

Para exemplificar melhor o que foi dito, nos capítulos 1 a 5 - Cusde capital - e 16 - Estrutura de capital e avaliação - o leitor consegue logo perceber o significado do famoso modelo de Modigliani e 
Miller e as controvérsias que dele se originaram, ou então o modelo de Myron Gordon sobre "precificação" de uma ação ordinária e/ou para a avaliação de uma empresa.

Ao final de cada capítulo, existe uma série de pequenos casos e/ou problemas para serem resolvidos, além de uma bibliografia básica muito boa (porém não muito sofisticadal.

O livro de Gitman é ideal para ser utilizado em um primeiro curso de administração financeira, onde os alunos podem ter uma noção elementar sobre o assunto, porém, na opinião do resenhista, junto com alguns capitulos de outros autores icomo Weston e Brigham: Financial management, hoje já na sexta edição, de 19781, ou então com preleções do professor, quando se pode aprofundar um pouco mais a matéria, uma vez que, apesar de atualizado, didático, simples na maneira de expor o assunto, o autor nem menciona algumas técnicas mais sofisticadas e já comprovadamente utilizadas na vida prática, como o CAPM lcapital assets pricing model), ou o OPM loptions pricing modell ou ainda 0 SPM (State preference model).

Infelizmente, existem pequenos lapsos na revisão feita pela editora, pois, embora raramente, ao invés de 10.000 ações encontramos o número 100.000 (e vice-versa); às vezes, também, foram omitidas uma ou duas linhas do original em inglês (a tradução possui 580 páginas, e o original, 649), fatos estes que podem confundir um pouco o leitor, mas que de modo algum tiram o mérito da obra e de sua tradução.

A editora também poderia fazer uma revisão melhor em alguns erros tipográficos. Por exemplo, na capítulo 10 - Administração de estoque - (p. 210), ao mostrar o' lote econômico de compra, fórmula (10.4), o denominador está errado, isto é, não é o número 2 , mas sim a letra $c$, como consta de maneira certa na nota de rodapé 5 . item (4) da mesma página. Todavia, o numerador que estava certo na fórmula $(10.4)$, ou seja $2 S(O)$, ou ainda 2 multiplicado por $S$ e depois multiplicado pela letra $O$, na. citada nota de rodapé o mesmo item saiu 20 (S), e com um tipo de impressão em que o número 2 parece que é multiplicado por zero e não pela letra $0 .$.

Acredito, todavia, que logo serão corrigidas estas pequenas fathas, as quais, conforme foi dito anteriormente, não tiram o mérito do livro. A qualidade da tradução, além da ótima impressão gráfica, com tabelas e gráficos fáceis de serem visualizados, e do fato de os tradutores, em vários capítulos iniciais - principalmente aqueles relacionados com a terceira parte A administração de capital de giro - terem colocado t.m notas de rodapé algumas das novidades introduzidas pela Lei n? 6.404 de 15.12.76 (Lei das Sociedades por Ações) e pelo Decreto-lei n. 1.598 de 26.12.77 (Altera a Legislação do Imposto sobre a Renda), fazem com que o livro de Gitman seja recomendado a todos aqueles que desejam iniciar-se no campo de administração financeira.

ivan Pinto Dias
Ideologia e educação brasileira - católicos e liberais.

Por Carlos Roberto Jamil Cury. São Paulo, Cortez e Moraes, $1978.201 \mathrm{p}$.

A recente explosão do mercado editorial nacional e o significativo aumento das publicações na área de ciências humanas trouxeram, também, um acréscimo aos estudos editados sobre educação. Os últimos lançamentos da tradicional Livraria Editora Francisco Alves e os da nova editora Cortez e Moraes evidenciam notória concentração de temas ligados ao ensino. Incluindo análises históricas, sociológicas e metodológicas das questões educacionais, apresentam coleções integradas por Bourdieu e Passeron, ou por jovens estudiosos que lançam os trabalhos acadêmicos que Ines valeram o grau de Mestre nos cursos de pós-graduação, como é o caso do presente ensaio de Carlos Roberto Jamil Cury. As duas editoras lançaram, entre 1977 e 1978, aproximadamente 15 títulos sobre educação, e isto parece indicar simultaneamente a expansão do mercado consumidor da literatura pedagógica e o aumento do interesse acadêmico sobre as questões relativas ao ensino.

Nesse quadro, surgiram vários estudos sobre a história da educação brasileira, e o tema da participação da Igreja como força ideológica nos debates e reformas educacionais no país mereceu duas publicações relevantes: a de Danilo Lima, Educação, Igreja e 